\title{
Interferon-Induced GTP-Binding Protein
} $\mathrm{Mx} 1$

National Cancer Institute

\section{Source}

National Cancer Institute. Interferon-Induced GTP-Binding Protein MX1. NCI Thesaurus.

Code C113311.

Interferon-induced GTP-binding protein Mx1 (662 aa, 76 kDa) is encoded by the human MX1 gene. This protein plays a role in GTP hydrolysis, apoptosis regulation and interferon signaling. 